\title{
Mount Cavallo Botanical Path: a proposal for the valorization of an area of the Orobie Bergamasche Regional Park (Southern Alps)
}

\section{Luca Giupponi \& Annamaria Giorgi}

Keywords: Orobie Bergamasche Regional Park, Orobic Alps, nature trail project, endemic species richness, ecological indices, nature tourism, Brembana Valley

\section{Abstract}

The identification of elements of special environmental interest present in protected areas is indispensable in order to fully valorize the resources of such areas. This is even more important in protected areas that have only recently been established, such as the Orobie Bergamasche Regional Park (Lombardy, Italy). This article reports the results of the analysis of the flora of the Mount Cavallo path, a little-known and little-used area of the Orobie Bergamasche Park. The floristic census conducted, which led to the identification of 241 species, showed that the study area has a high number of endemic (some of which are steno-endemic) and/or rare plants, including Linaria tonzigii Lona, which is also a species of community interest. Given the wealth and significance of the floral heritage of the study area, as well as its unique geological and environmental characteristics, a proposal is presented for its valorization, involving the construction of a nature trail: the Mount Cavallo Botanical Path. This study, which presents the distribution maps of the various endemic species along the path and the results of the chorological and ecological analyses of the local flora, provides the scientific background knowledge for the development of a project for the promotion and enhancement of one of the most interesting and beautiful areas of the Orobie Bergamasche Park.
Profile

Protected area

Orobie Bergamasche

Regional Park

Mountain range

Alps

Country

Italy

\section{Introduction}

The valorization of the natural elements that characterize protected areas can be important in attracting attention to environmental issues and nature conservation, which are important objectives for protected areas in the $21^{\text {st }}$ century (Mose 2007). In order to enhance the natural heritage of a protected area, however, we must first identify the valuable elements that it presents. Today more than ever therefore, researchers, especially those who deal with environmental issues, are called upon to produce studies that identify and characterize the unique features of protected areas, such as those within the European Alpine region, because these areas can represent valuable resources for the sustainable development of territories (Giorgi \& Scheurer 2015).

In the Alps, there are more than 900 protected areas (parks, natural reserves, Sites of Community Importance (SCIs), Special Protection Areas, UNESCO biosphere reserves etc.) (ALPARC 2016), some of which are managed by institutions whose economic (and human) resources are unfortunately too limited to conduct scientific research related to their territories. In these cases, only co-operation between protected areas and universities and/or research centres can overcome this hurdle. This article gives an example of how university research centres that deal with the protection and sustainable development of a territory can, and should, provide scientific contributions and proposals for the development of protected areas and their elements of environmental interest. We focus on the Ge.S.Di.Mont. centre (Centre for Applied Studies in the Sustainable Management and Protection of the Mountain Environment). In particular, this paper reports the results of a floristic analysis carried out in the Mt Cavallo area of the Orobie Bergamasche Regional Park (RP), Italian Alps. The Mt Cavallo area is rich in endemic and / or rare species, but is little known (and little used) and deserving of attention, considering the continuous increase in nature tourism in Europe (Bell et al. 2007). The analysis was carried out with the aim of enhancing the floristic and environmental knowledge of the area so as to highlight its special features and therefore put forward a proposal for its valorization. Ge.S.Di.Mont. researchers carried out this particular study because the Orobie Bergamasche RP, the largest of the regional parks in Lombardy $(70000$ hectares) with high naturalness, having been established relatively recently (LR 15/09/1989 n. 56), still requires studies which contribute to the valorization of its elements of environmental interest.

\section{Study area}

Mt Cavallo is located in the Orobie Bergamasche RP (Brembana Valley, Lombardy, Northern Italy; $46^{\circ} 02^{\prime} 04.24 ” \mathrm{~N}, 09^{\circ} 41^{\prime} 25.09 \mathrm{E}$ ) (Figure 1). The park is an important plant area of Italy (Blasi et al. 2011), and is situated within one of the richest sites in Berga- 
Table 1 - Floristic features of the Mt Cavallo path: endemic species (subendemic, endemic to the Alps, and endemic to Italy), and / or rare (R), and / or very rare (RR), in Central-Eastern Lombardy. The species are listed by family; the life form is according to Raunkiaer (1934). PF = less frequent species.

\begin{tabular}{|c|c|c|c|c|c|}
\hline No. & Species & Family & Life form & Chorotype & Freq \\
\hline 1 & Allium victorialis $\mathrm{L}$. & Alliaceae & G bulb & Circumbor. & $R$ \\
\hline 2 & Allium insubricum Boiss. \& Reuter & Alliaceae & G bulb & Endem. & $R$ \\
\hline 3 & Linaria tonzigii Lona & Antirrhinaceae & Ch suffr & Endem. & RR \\
\hline 4 & Laserpitium halleri Crantz subsp. halleri & Apiaceae & H scap & Endem. & PF \\
\hline 5 & Bupleurum petraeum L. & Apiaceae & H scap & Endem. Alp. & $R$ \\
\hline 6 & Bupleurum stellatum L. & Apiaceae & H scap & Endem. Alp.-Cors. & PF \\
\hline 7 & Carduus defloratus subsp. tridentinus (Evers.) Ladurner & Asteraceae & H scap & Endem. Alp. & $\mathrm{F}$ \\
\hline 8 & Schlagintweitia intybacea (All.) Griseb. & Asteraceae & H scap & Endem. Alp. & PF \\
\hline 9 & Senecio cordatus Koch & Asteraceae & H scap & Endem. E-Alp. & PF \\
\hline 10 & Crepis jacquinii subsp. kerneri (Rech. f.) Merxm. & Asteraceae & $\mathrm{H}$ ros & Orof. SE-Europ. & $R$ \\
\hline 11 & Centaurea rhaetica Moritzi & Asteraceae & H scap & Subendem. & PF \\
\hline 12 & Thlaspi rotundifolium (L.) Gaudin subsp. rotundifolium & Brassicaceae & Ch suffr & Endem. Alp. & $R$ \\
\hline 13 & Petrocallis pyrenaica (L.) R. Br. & Brassicaceae & $\mathrm{H}$ ros & Orof. S-Europ. & $R$ \\
\hline 14 & Barbarea bracteosa Guss. & Brassicaceae & H scap & Orof. S-Medit. & $R$ \\
\hline 15 & Campanula raineri Perp. & Campanulaceae & H scap & Endem. & $\mathrm{PF}$ \\
\hline 16 & Campanula barbata L. & Campanulaceae & H scap & Endem. Alp. & PF \\
\hline 17 & Phyteuma betonicifolium Vill. & Campanulaceae & H scap & Endem. Alp. & $\mathrm{F}$ \\
\hline 18 & Cerastium latifolium L. & Caryophyllaceae & Ch suffr & Alp.-W-Carpatic & $\mathrm{R}$ \\
\hline 19 & Minuartia rupestris (Scop.) Schinz \&Thell. & Caryophyllaceae & Ch suffr & Endem. Alp. & $R$ \\
\hline 20 & Minuartia austriaca (Jacq.) Hayek & Caryophyllaceae & Ch suffr & Endem. Alp. & RR \\
\hline 21 & Carex austroalpina Bech. & Cyperaceae & H caesp & Endem. & PF \\
\hline 22 & Rhododendron hirsutum L. & Ericaceae & NP & Endem. Alp. & PF \\
\hline 23 & Hedysarum hedysaroides subsp. exaltatum (A. Kern.) Chrtk.-Zert. & Fabaceae & H scap & Artic-Alp. (Europ.) & $R$ \\
\hline 24 & Anthyllis vulneraria L. subsp. baldensis (A. Kern.) Becker & Fabaceae & H scap & Endem. & PF \\
\hline 25 & Oxytropis neglecta Ten & Fabaceae & H scap & Orof. S-Europ. & RR \\
\hline 26 & Gentianella anisodonta (Borbás) Á. \& D. Löve & Gentianaceae & H bienn & Endem. Alp.-Appenn. & PF \\
\hline 27 & Gentiana purpurea L. & Gentianaceae & H scap & Orof. W-Europ. & $R$ \\
\hline 28 & Globularia cordifolia L. & Globulariaceae & Ch rept & Endem. Alp. & $\mathrm{F}$ \\
\hline 29 & Hypericum richeri Vill. & Hypericaceae & H scap & S-Europ.-S-Sib. & $\mathrm{R}$ \\
\hline 30 & Epilobium alpestre (Jacq.) Krock. & Onagraceae & H scap & Orof. S-Europ. & $\mathrm{R}$ \\
\hline 31 & Euphrasia hirtella Jord. ex Reut. & Orobanchaceae & T scap & Circumbor. & $\mathrm{R}$ \\
\hline 32 & Pedicularis ascendens Schleich. ex Gaudin & Orobanchaceae & $\mathrm{H}$ ros & Endem. W-Alp. & $R$ \\
\hline 33 & Euphrasia officinalis subsp. picta (Wimm.) Oborný & Orobanchaceae & T scap & Orof. C-Europ. & RR \\
\hline 34 & Pedicularis gyroflexa Vill. & Orobanchaceae & $\mathrm{H}$ ros & Subendem. & PF \\
\hline 35 & Helictotrichon parlatorei (Woods) Pilg. & Poaceae & H caesp & Endem. Alp. & PF \\
\hline 36 & Poa cenisia All. & Poaceae & H caesp & Endem. Alp. & RR \\
\hline 37 & Festuca scabriculmis subsp. luedii Markgr.-Dann. & Poaceae & H caesp & Endem. SW-Alp. & PF \\
\hline 38 & Trisetum distichophyllum subsp. brevifolium (Host) Pign. & Poaceae & G rhiz & Orof. S-Europ. & $R$ \\
\hline 39 & Trisetum alpestre (Host) P. Beauv. & Poaceae & H caesp & Orof. SE-Europ. & $R$ \\
\hline 40 & Primula glaucescens Moretti & Primulaceae & $\mathrm{H}$ ros & Endem. & PF \\
\hline 41 & Ranunculus montanus Willd. & Ranunculaceae & H scap & Endem. Alp. & $\mathrm{PF}$ \\
\hline 42 & Aquilegia einseleana F.W. Schultz & Ranunculaceae & H scap & Endem. Alp. & PF \\
\hline 43 & Potentilla nitida L. & Rosaceae & Ch rept & Subendem. & $\mathrm{R}$ \\
\hline 44 & Galium baldense Spreng. & Rubiaceae & H scap & Endem. & $\mathrm{R}$ \\
\hline 45 & Saxifraga hostii subsp. rhaetica (A. Kern.) Braun-Blanq. & Saxifragaceae & $\mathrm{H}$ ros & Endem. & $\mathrm{PF}$ \\
\hline 46 & Saxifraga vandellii Sternb. & Saxifragaceae & Ch pulv & Endem. & PF \\
\hline 47 & Saxifraga exarata subsp. moschata (Wulf.) Cavill. & Saxifragaceae & H scap & Euro-Asiat. & $R$ \\
\hline 48 & Daphne striata Tratt. & Thymelaeaceae & Ch suffr & Endem. Alp. & PF \\
\hline 49 & Valeriana saxatilis L. & Valerianaceae & H scap & Endem. Alp. & PF \\
\hline
\end{tabular}

mo for endemic plant species (Martini et al. 2012). The peak of Mt Cavallo reaches $2323 \mathrm{~m}$ a.s.l. and forms the boundary between three municipalities: Mezzoldo, Valleve and Piazzatorre. It can be reached from the San Simone Pass (located north of Mt Cavallo at an altitude of $2106 \mathrm{~m}$ a.s.l.) thanks to a path that runs along the eastern slopes and the ridge. This path, and indeed the one which from the top of Mt Cavallo descends the western ridge and slopes to rejoin the eastern path at the San Simone Pass, is not marked on the Club Alpino Italiano's (CAI) geoportal or on recent maps produced by the Club. These paths are rarely used and at some points peter out (especially the western path). The only hiking paths marked on CAI maps are those that lead to the San Simone Pass from the San Simone basin (Valleve) or from Mezzoldo (Terzera Valley). 


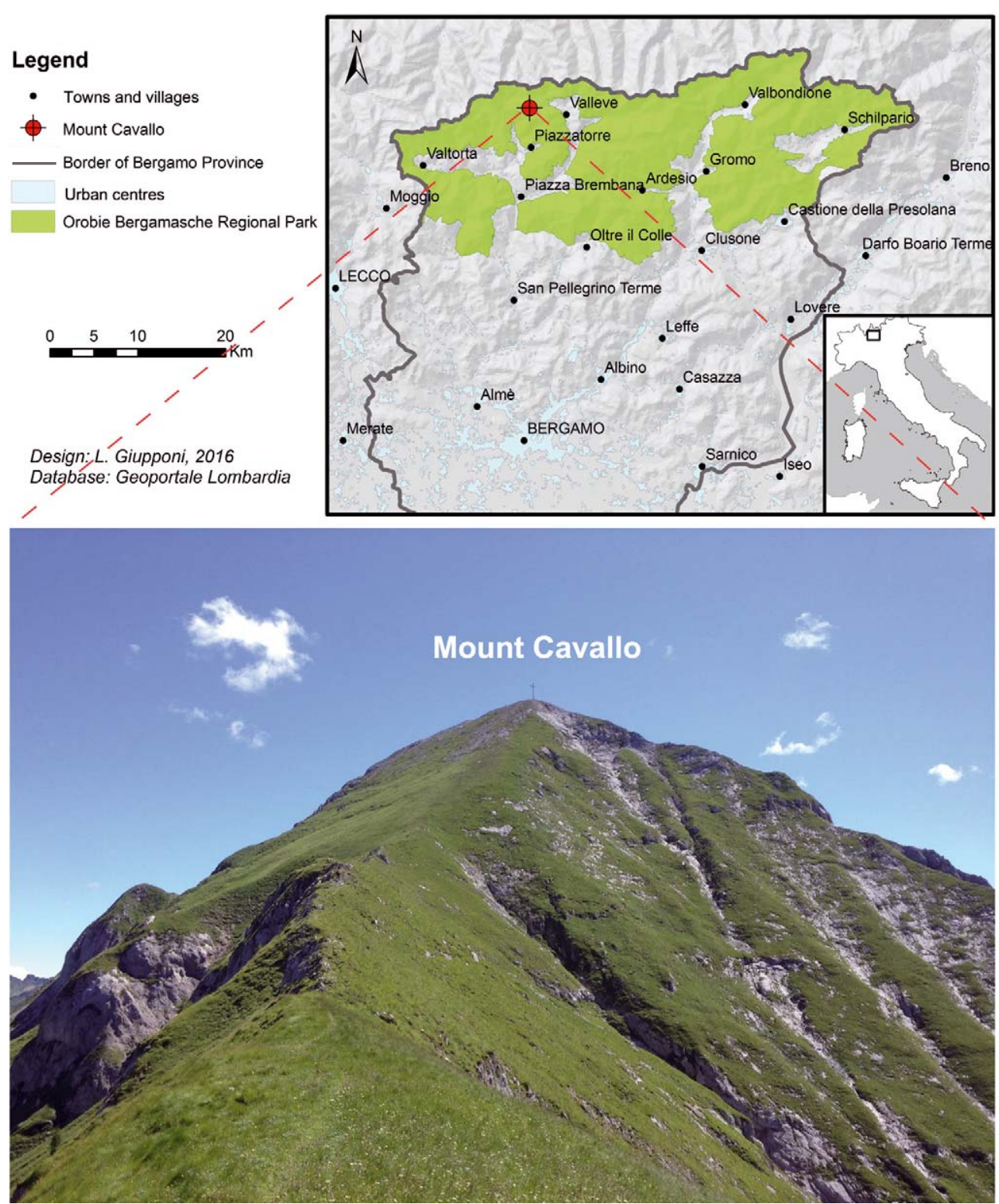

Figure 1 - Location of the study area. The photograph shows the S/W slope of Mt Cavallo. (C) L. Giupponi

In geological terms, an E-W thrust (Orobic Thrust) separating the Permo-Triassic rocks (mainly limestone and conglomerates) to the south from the more ancient metamorphic rocks (mainly mica schists) to the north runs close to the San Simone Pass (D'Adda \& Zanchetta 2015; Provincia di Bergamo et al. 2000). The varying characteristics of the bedrock affect the vegetation: to the south of the San Simone Pass (and therefore also on Mt Cavallo), there are mostly basophilous grasslands of Caricion austroalpinae and Caricion firmae (Sutter 1962; Pignatti \& Pignatti 1975, 2014; Ravazzi 1992), while to the north of the pass mainly acidophilous Festuca scabriculmis grasslands (Andreis \& Rinaldi 1989) are present. The study area belongs to the South-Orobic Geobotanical District (Andreis 2002), which is characterized by a pre-Alpine sub-oceanic climate; according to the recent classification of the ecoregions of Italy, it is part of the Central and Eastern Alps section of the Alpine Province (Blasi et al. 2014). As for the vegetation dynamics, Mt Cavallo belongs to the pre-Alpine Central and Eastern geosigmetum of Carex firma grasslands and Sesleria varia basophilous grasslands. This geosigmetum includes, among other series, the lithophile series of PotentilloTelekietum speciosissimae and Thlaspion rotundifolii, the edaphic series of Tofieldio calyculatae-Caricetum firmae, and the climacical series of esalpic grasslands Sesleria varia (Caricion austroalpinae, Seslerio-Cytisetum emeriflori) and Rhodothamno-Rhododendretum birsuti (Verde et al. 2010). After World War II, and especially in the 1960s, the San Simone basin underwent major anthropogenic intervention involving remodelling of the mountain slopes in order to create numerous ski runs, one of which starts right at the San Simone Pass. The San Simone ski facilities are still in use in winter months, even though snowfall continues to decrease. 


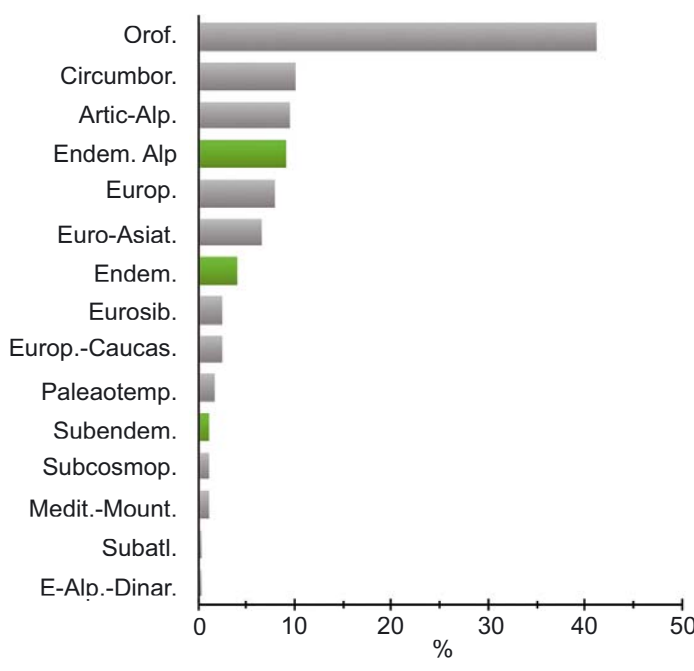

Figure 2 - Simplified chorological spectrum of the flora of the Mt Cavallo path. The green bars highlight the frequency of the endemic species of the Alps (9.2\%), the endemic species of Italy $(4.2 \%)$, and the subendemic species (1.2\%).

\section{Materials and methods}

In the summer months (June-September) of 2016, a census of the species present along the two paths (eastern and western) which lead from the San Simone Pass to the summit of Mt Cavallo was carried out, identifying the species observed on the entire circular route (eastern and western paths combined), including those within a belt about 6 metres wide $(3$ metres upslope and 3 metres downslope from the path). Species were identified using the floristic keys of Pignatti (1982) and Aeschimann and Burdet (1989), the latter being used mainly for species identification in the field. Data referring to the chorological type of each species was extrapolated from Pignatti (1982), while data on the rarity of species in Central and Eastern Lombardy were taken from Martini et al. (2012). In order to highlight the ecological characteristics of the flora of the study area, an ecological spectrum was elaborated by using the ecological indices of Landolt et al. (2010). The whole path was georeferenced using a GPS device, as were points where endemic species were present. The data collected via GPS were then processed to produce thematic maps using ArcGIS 10 software (®Esri, Redlands, CA, USA). Principal Component Analysis (PCA) was conducted using the vegan package (Dixon 2003) of the R 3.3.2 software (R Development Core Team 2015), in order to identify the main ecological gradients that determine the distribution of the species surveyed. The scientific names of the species are those of Martini et al. (2012).

\section{Results}

The floristic census resulted in the identification of 241 plant species, of which $8 \%$ are rare and $2 \%$ are very rare in Central and Estern Lombardy. Most of the species surveyed flower between June and August, according to Körner (2003). Figure 2 shows the chorological spectrum of the flora of the Mt Cavallo path, highlighting that the most common chorological type is represented by orophytes, followed by circumboreals and arctic-alpines. Endemic species in a broad sense (endemic to Italy, subendemic and endemic to the Alps (Pignatti 1982)) represent $14.6 \%$ of the flora list. Table 1 lists the species of special interest present along the Mt Cavallo path: the endemic and/ or rare (R) and very rare (RR) species according to Martini et al. (2012). There are ten endemic Italian species, including Linaria tonzigii (Lona 1949; Fenaroli 1954) (Figure 3). This species is present only in the province of Bergamo (Pignatti 1982; Aeschimann et al. 2004), where it has been reported in a few locations (Bendotti 1996; Valoti 1996; Martini et al. 2012), always on limestone screes of Calcare di Esino formation (Upper Anisian - Ladinian), like those found along the eastern stretch of the Mt Cavallo path. Linaria tonzigii is, moreover, also a species of community interest included in Annex II of the Habitats Directive (92/43/ EEC), the most important European legislation for nature conservation. Nevertheless, the study area is not part of any SCI.

Figure 4 shows the Mt Cavallo circular path, with the points at which the various endemic Italian species are located; some are frequent along the entire route (Primula glaucescens, Saxifraga hostii subsp. rhaetica, $A n$ thyllis vulneraria subsp. baldensis, and Carex austroalpina), while others are rarer or more localized (Linaria tonzigii, Allium insubricum, Laserpitium halleri subsp. halleri, Campanula raineri, Saxifraga vandellii and Galium baldense). The path is about $4 \mathrm{~km}$ long, has a variation in altitude of $400 \mathrm{~m}$, and can be covered in about two hours walking, starting from the San Simone Pass. The Pass itself can be reached from the San Simone ski centre (in about 45 minutes on foot) or from Terzera Valley (in about an hour and a half on foot). The graph in Figure 5 shows that, from an ecological point of view, most of the species surveyed are heliophilous microthermal species living on basic, dry and nutrient-poor substrates. In fact, most of them are typical of rocky environment communities (Potentillion caulescentis), limestone screes (Thlaspion rotundifolii), and basophilous grasslands ( $\mathrm{Ca}$ ricion austroalpinae / Caricion firmae), although there are various species of Festucion variae localized in the short stretch in which the path is on acid substrate (section E, Figure 4). There are also some megaforbs (Adenostylion alliariae), which can be observed in the valleys where water occasionally flows and nutrients accumulate.

Near the San Simone Pass, where a ski run starts, there are a few meadow species (Molinio-Arrhenatheretea) typical of lower-altitude environments (e. g. Lolium perenne, Festuca pratensis, Trifolium repens and Agrostis capilla$r i s)$ that were most probably sown by man when work on the ski run was finished. Based on our observations, these species would not seem to have spread beyond the ski run. 
The biplots provided by PCA (Figure 6) shows two main ecological gradients that determine the distribution of the species in the study area: the first corresponds to the PC1 axis along which, from left to right, the heliophylous species of well-aerated substrates (rocks and screes) decrease, while those living on deeper, moist, nutrient-rich soils (grasslands and communities of megaforbs) increase. The second correspond to the PC2 axis along which the species are positioned according to substrate reaction (R). In fact, from the bottom to the top of the PC2 axis the acidophilic species which require a substantial amount of humus in the soil decrease while basophilic species that require soils poor in humus increase. The characteristics of the substrate would seem to be the ecological variables that influence the distribution of species (and probably also the plant communities) most significantly along the path.

\section{Discussion}

The results provided by this research have highlighted the richness of the floral heritage of the Mt Cavallo path, as seen especially by the presence of a large contingent of endemic species (some of which are steno-endemic) and / or rare ones (Table 1). These data confirm those reported in Martini et al. (2012). The richness of endemic species found in the study area is supported by the fact that, according to Pawlowski (1970), the pre-Alpine district of Lombardy, with 31 endemic higher plant taxa, is the second most important centre of endemism in the Alpine chain. Although numerous endemic species were identified along the path, Telekia speciosissima (L.) Less., an endemic species of Lombardy and Trentino (Pignatti 1982), was not found, despite its being widespread on the carbonate rocks in the Orobie Bergamasche RP; nor was Potentilla caulescens. These two species give their names to an endemic lithophile association: Potentillo-Telekietum speciosissimae. Both species are probably unable to survive the cold temperatures due to the altitude at which the Mt Cavallo path is situated, although, in more southerly stations (like those near Pizzo Arera), both can be found up to about $2000 \mathrm{~m}$ (authors' observations). Low temperatures could also explain the absence of Silene elisabethae Jan (an endemic species of Lombardy and Western Trentino). In the Lombardy pre-Alps, at around 1600 to $2100 \mathrm{~m}$ a.s.l., Silene elisabethae, together with other species with a steno-endemic or disjunct distribution, such as Galium baldense, Ranunculus bilobus Bertol., Minuartia grignensis (Rchb.) Mattf., and Scabiosa vestina Facchini ex W.D.J. Koch, makes up the relict endemic contingent of Carex firma grasslands (Ravazzi 1992).

Another point that has emerged from the data collected in the flora census (and from field observations) is the absence of Pinus mugo Turra along the path and in adjacent areas potentially suitable for the species. The dwarf mountain-pine, which is very common in
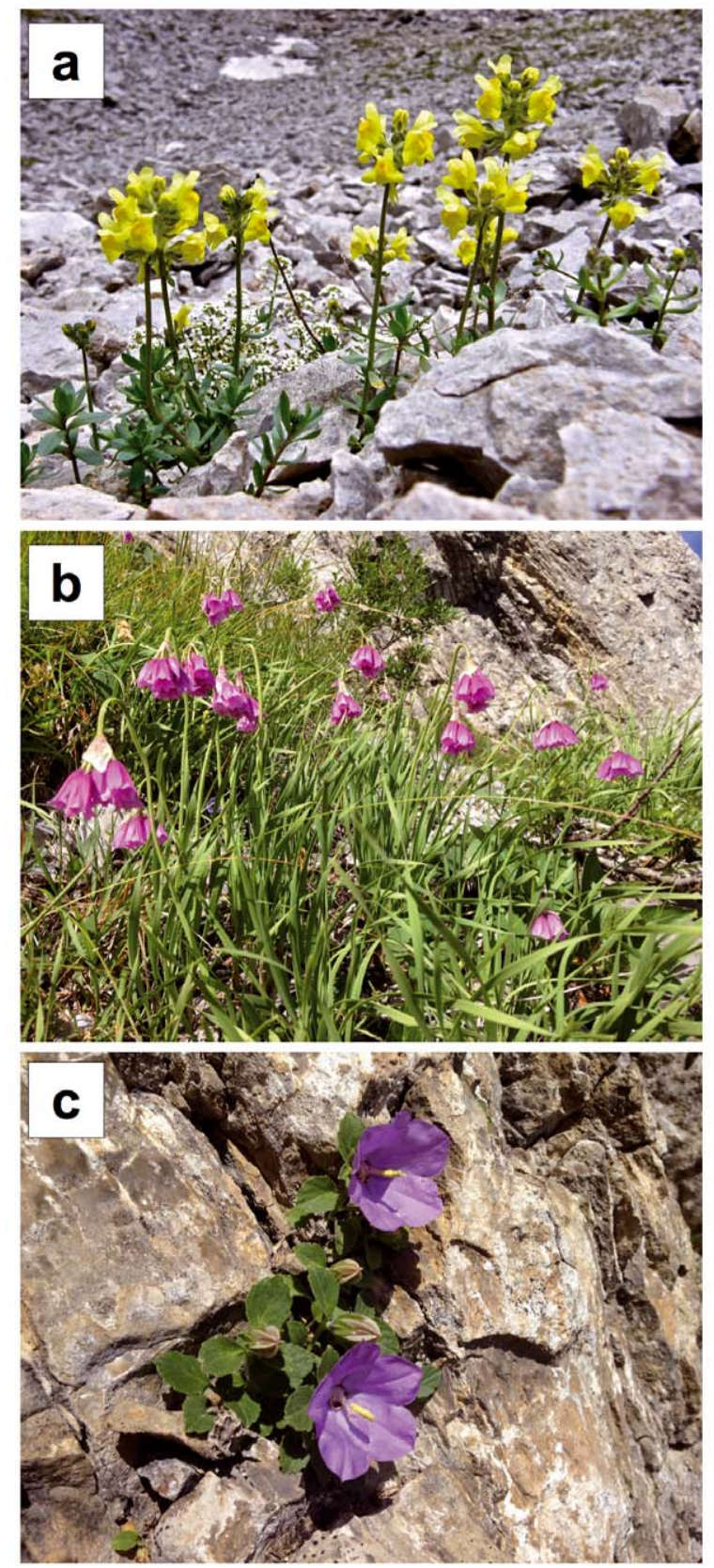

Figure 3 - Some endemic species along the Mt Cavallo path: (a) Linaria tonzigii; (b) Allium insubricum; (c) Campanula raineri. (C) L. Giupponi

the limestone-dolomite screes and cliffs of the Alps at an altitude ranging from 1500 to $2700 \mathrm{~m}$, is found in the study area at lower altitudes up to the foothills of Monte Pegherolo (at about 1900 m a.s.l.), a few hundred metres to the south of Mt Cavallo. Its absence in the areas near the path (as well as from the whole of Mt Cavallo) could be due to Pinus mugo, with its heavy seeds, having difficulty in colonizing the rock faces and screes at altitudes higher than those where it is already located. The dwarf mountain-pine would be able to colonize the rock faces, screes and gullies of Mt Cavallo only from the south, where limestone is found: to the north of Mt Cavallo, there are no limestone massifs within the province of Bergamo (Provincia di 

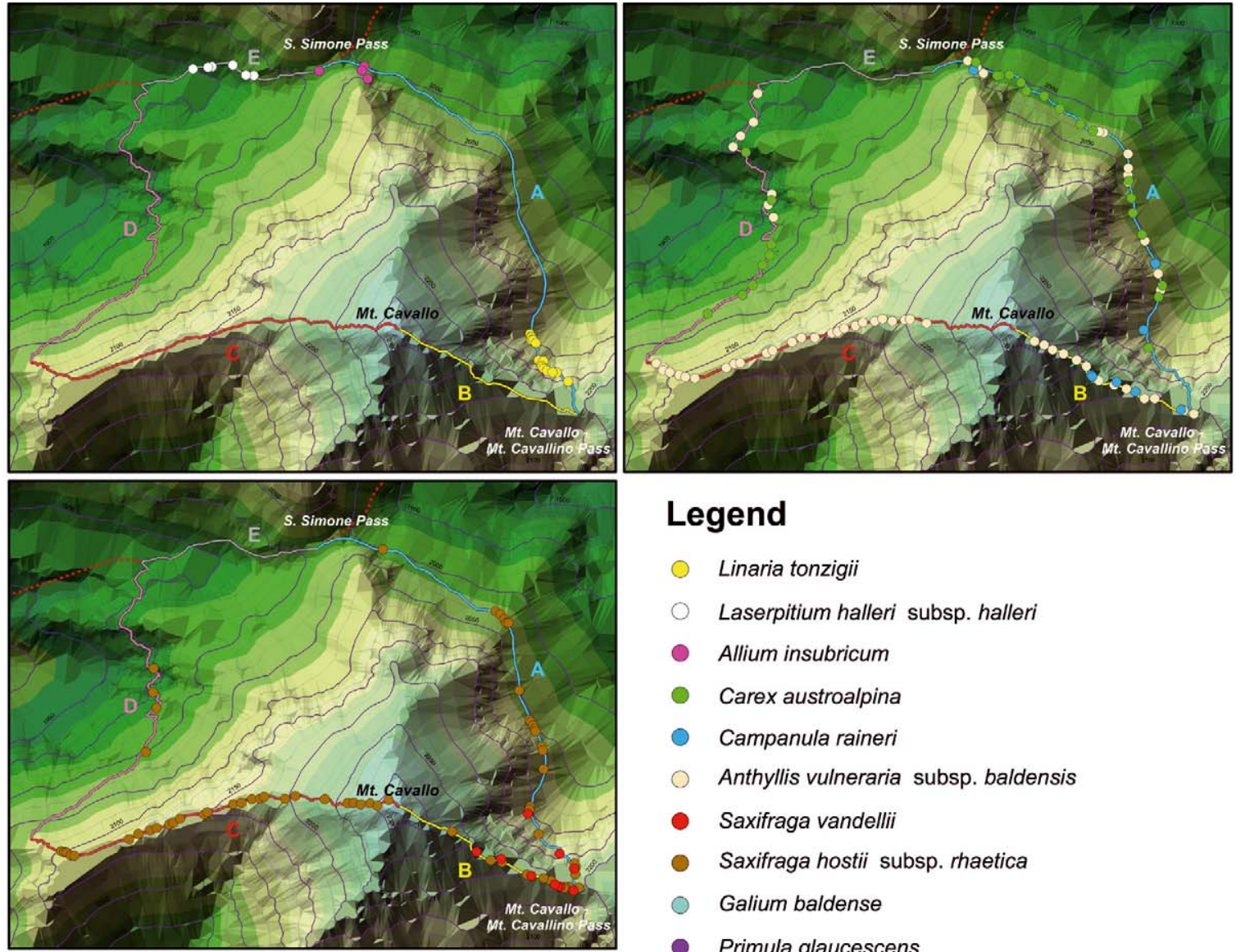

\section{Legend}

- Linaria tonzigii

- Laserpitium halleri subsp. halleri

- Allium insubricum

- Carex austroalpina

- Campanula raineri

- Anthyllis vulneraria subsp. baldensis

- Saxifraga vandellii

- Saxifraga hostii subsp. rhaetica

- Galium baldense

- Primula glaucescens

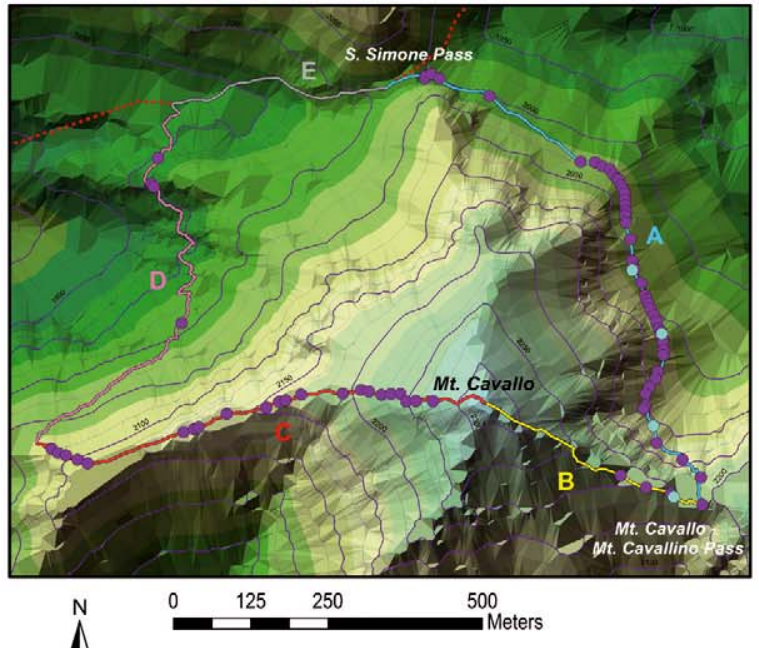

Mount Cavallo

Section A

Section B

Section C

Section D

Section E

Elevation ( $m$ a.s.I.)

A

Design: L. Giupponi, 2016 Database: Geoportale Lombardia

Figure 4 - Localization of endemic species on the Mt Cavallo path. The path has been divided into five sections with different topographical and geopedological characteristics: A: San Simone Pass - Mt Cavallo / Mt Cavallino Pass; B: Mt Cavallo / Mt Cavallino Pass - Mt Cavallo summit (Eastern Ridge); C: western ridge; D: section along the western slopes; E: section on acid substrate (Terzera Valley).

Bergamo et al. 2000). Pinus mugo, in spreading towards Mt Cavallo, would find environments (screes and/or rocks) suitable for its propagation and growth, but such areas are often interrupted by Caricion austroalpinae grasslands that can hinder the expansion of the dwarf mountain-pine. This hypothesis regarding the absence of Pinus mugo on Mt Cavallo should, however, be supported by appropriate scientific studies. Furthermore, it would be interesting to study an isolated occurrence of Allium victorialis, a rare species (Table 1) which has been observed only in a small area along the path along the western ridge of Mt Cavallo (section C, Figure 4).

The results returned by the ecological spectrum (Figure 5) and by PCA (Figure 6) allow the identification of the main ecological gradients that determine the distribution of the species in the study area, and 
therefore of the main environments present. Most of the species were found to be typical of the limestone cliffs and screes which, together with basophile grasslands, are the most extensive environments in the study area and those where all the endemic species except Laserpitium hallerii are located. The latter, due to its ecological requirements, is present only in the stretch where the path runs on acid substrate (section E, Figure 4). The thrust that near the San Simone Pass separates the acidic rocks to the north from the basic rocks to the south is therefore an insurmountable ecological barrier, both for the typically basophile species (which are unable to spread northwards) and for those typically acidophile species (which cannot spread towards the south). The acidic and basic rocks thus contribute significantly to the diversification of the plant landscape of the study area, increasing its environmental value.

From the list of endemic species (Table 1), as well as from their distribution along the path (Figure 4), it is clear that most (nine out of ten) are basophile. This characteristic, as well as being explained by the fact that the path runs almost entirely on limestone substrate, is due to the fact that the southern carbonate pre-Alps are much richer in endemic species than the inner Alps. This itself is explained by the fact that many south-facing areas of the Lombardy pre-Alps were refuge zones during the glaciations of the Quaternary Age (Giacomini \& Fenaroli 1958; Pitschmann \& Reisigl 1959; Reisigl 1995; Reisigl \& Keller 1990).

It would be interesting to conduct further scientific research in the study area to integrate with that on the flora, such as vegetation and geopedological analyses, in order to highlight other natural features to be valorized and protected. From the floristic analysis alone, it is clear that, from a conservation point of view, the area of Mt Cavallo should be better protected. The presence of Linaria tonzigii (a species of community interest) merits the inclusion of the study area (or part of it) in a SCI that should be added to the list of 193 SCIs in Lombardy (Casale et al. 2008). This could prevent the loss of biodiversity due to a possible future expansion of the San Simone ski area. Greater protection of the area is also justified by the presence not only of endemic / rare species along the path, but also of other species of remarkable floristic significance. Although they are not found within the development belt of the path, the study area includes, for example, Androsace lactea L., Cirsium heterophyllum (L.) Hill (only site in Bergamo province), Fritillaria tubiformis Gren. \& Godr., Oxytropis montana (L.) DC., Saxifraga presolanensis Engler (the westernmost site of the distribution area), Sempervivum wulfenii Hoppe ex Mert. \& W.D.J. Koch, and Telekia speciosissima (L.) (data provided by Flora Alpina Bergamasca (FAB)).

The floristic heritage of Mt Cavallo deserves to be valorized by creating, for example, a botanical path for researchers, students and, more generally, those interested in natural sciences and hiking.

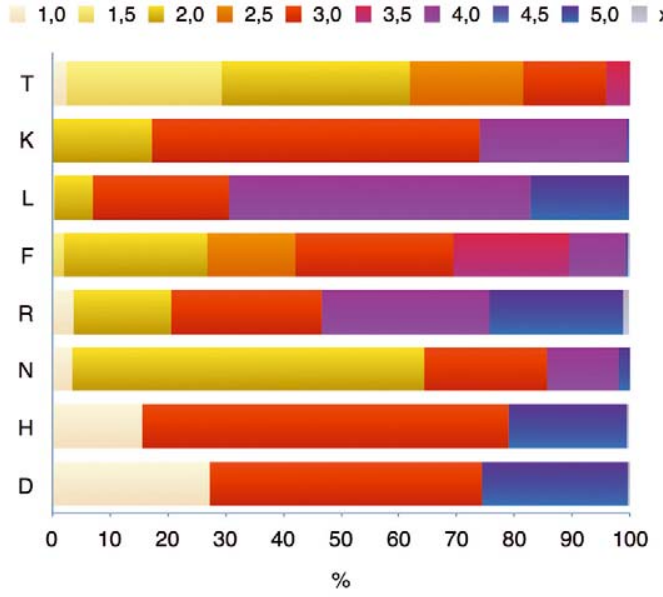

Figure 5 - Ecological spectrum of flora list. T, temperature; $K$, continentality; L, light; F, moisture; $R$, reaction; $N$, nutrients; H, bumus; D, aeration (Landolt et al. 2010).

In the Orobie Bergamasche RP, there is already a mountain path along which various endemic plants of the Orobie pre-Alps can be observed: the Sentiero dei Fiori Alpe Arera (Mount Arera Path of Flowers, Brissoni 2007), in the municipality of Oltre il Colle. In recent years, this path, which is also known by the name of the botanist to whom it was dedicated (Prof. Claudio Brissoni), has been well exploited and publicized by the park and by the FAB Association, so much so that nowadays during the summer months many tourists (Italian and foreign) visit this area, which is south of Mt Cavallo. The Mt Cavallo path, which is as rich in endemic / rare species but much shorter and less demanding from a hiker's point of view than the Mt Arera path, could be valorized in a similar way, especially since it would be more suitable for those who are not accustomed to long and strenuous mountain hikes. Moreover, the Mt Cavallo path, due to its particular location along a line separating basic from acid rocks, allows the observation of the main basophilic and acidophilic species and plant communities that characterize the different environments of the mountain and subalpine belt of the Orobie Bergamasche RP. The census of the species present along the path and the georeferencing of the trail could be the first step towards the creation of the Mount Cavallo Botanical Path, followed by the preparation of an illustrated guide showing the characteristics of the various species. In some locations, the path would have to be renovated and made safe. Georeferenced points indicating the location of the endemic species along the route could be used not only to track the spread/regression of the species over time but also to find the best positions in which to place information panels. Such data could also be useful for developing interactive apps that allow tourists to visit the points of special interest on the path. These mobile applications have already been adopted in some parks (Melo et al. 2014) and, given the speed with which new information technolo- 
a)

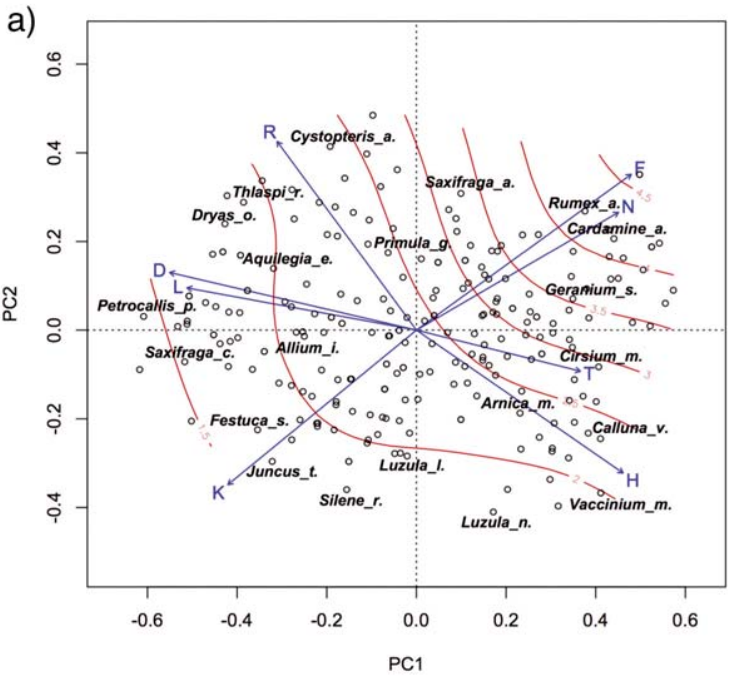

b)

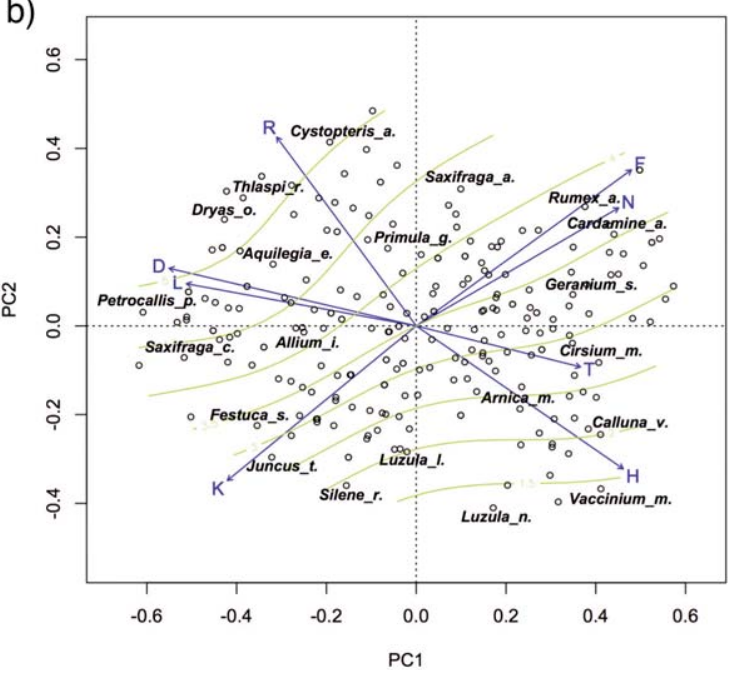

Figure 6 - Biplots of PCA (explained variance: PC1 = $42.52 \%$; PC2 $=16.69 \%$ ) overlaid with a smooth fitted surface of estimated $N$ - soil nutrients (Figure 6a), and R - soil reaction (Figure 6b), fitted using a generalized additive model using the $\mathrm{R}$ function ordisurf. The eight variables (ecological indexes of Landolt: $T$, temperature; $K$, continentality; L, Light; $F$, moisture; $R$, reaction; $N$, nutrients; $H$, bumus; $D$, aeration) are represented by a vector, while the circles indicate the species. Some species are highlighted: Cystopteris_a., Cystopteris alpina; Saxifraga_a., Saxifraga aizoides; Thlaspi_r., Thlaspi rotundifolium subsp. rotundifolium; Rumex_a., Rumex alpinus; Dryas_o., Dryas octopetala; Cardamine_a., Cardamine asarifolia; Primula_g., Primula glaucescens; Aquilegia_e., Aquilegia einseleana; Geranium_s., Geranium sylvaticum; Petrocallis__., Petrocallis pyrenaica; Allium_i., Allium insubricum, Saxifraga_c., Saxifraga caesia; Cirsium_m., Cirsium montanum; Arnica_m., Arnica montana; Festuca_s., Festuca scabriculmis subsp. luedii; Calluna_v., Calluna vulgaris; Luzula_l., Luzula lutea; Juncus_t., Juncus trifidus; Silene_r., Silene rupestris; Vaccinium_m., Vaccinium myrtillus; Luqula_n., Luzula nivea. gies are spreading, could soon be used widely in many other protected areas, hence facilitating and enhancing tourists' visits.

While encouraging tourists to visit natural areas like Mt Cavallo would promote greater awareness of issues concerning nature and the environment, it could, on the other hand, lead to threats to the natural heritage (Ciapała et al. 2014). Such threats could be due to poor management and / or presented by the behaviour of tourists, or even simply the mere presence of people, such as disturbance caused by noise pollution (affecting the fauna) or the trampling of plants of great interest. According to Bell et al. (2007), in some Central European countries, the conflicts between the demands of tourism and recreation on the one hand, and nature conservation priorities on the other, especially in areas where more stringent nature conservation measures are in force, can be resolved through the constant monitoring of the impacts of tourists on the environment. Sound management of tourism in protected areas is therefore required.

Metsähallitus, the state Forest and Park Service in Finland, has developed nine principles which summarize the key elements of managing sustainable nature tourism in protected areas (Metsähallitus 2000). Although these guidelines meet with broad consensus among those involved in the valorization of protected areas, the integration of nature tourism with the management of protected areas in Europe remains a key issue on which to conduct research in order to develop and constantly improve strategies of action (Eagles 2009; Hammer et al. 2012; Hammer \& Siegrist 2008; McCool 2006; Newsome et al 2009). However, in our opinion, valid actions to prevent tourism having a negative impact on the nature of a protected area such as the one we studied might be: the creation of a calendar of hiking tours operated by experienced guides (which is already the case in many parks, including the Orobie Bergamasche RP); the promotion of environmental education activities; and the provision of a good network of staff (such as park wardens or rangers, or voluntary ecological guards) to monitor the behaviour of tourists in the field, penalizing them in the case of unlawful conduct, as is already the case in many Italian parks, including those in Lombardy. As long ago as 1980, the Lombardy Region established the Volunteer Ecological Surveillance Service (currently governed by Regional Law 28/02/2005 n. 9), which encourages the participation of citizens (Voluntary Ecological Guards, GEVs) in the protection of the regional natural heritage and landscape. This service is active in many parks, including the North Milan park, the Agricultural Park of South Milan, the Ticino Park, the South Adda Park, the Mincio Park, the North Oglio Park, the Adamello Park, the Orobie Valtellinesi Park and, indeed, the Orobie Bergamasche RP. 


\section{Conclusion}

In conclusion, this study has not only widened botanical knowledge of the Orobie Bergamasche RP and highlighted the peculiarities of the flora in the study area, but has also provided a starting point from which to develop a project for the valorization of this area: the creation of the Mount Cavallo Botanical Path. Scientific research, as in this case, could be helpful for the valorization of protected areas, and should be promoted with greater energy by research centres and universities, especially in view of the fact that nature conservation and biodiversity are issues which now attract great interest and concern (Körner 2014; Palombo et al. 2014; Sandifer et al. 2015; Admiraal et al. 2016). The valorization of protected areas is, however, also (and especially) the responsibility of local land managers, who need to be aware of and implement the ideas that come from the world of research. In this case, it will be the task of the managers of the various local institutions, supported by specialized technicians and researchers, to try to establish the Mount Cavallo Botanical Path, which could allow people to enjoy the natural heritage of Mt Cavallo, without spoiling or altering the ecosystems. This is one of the most noble and ambitious goals which those who manage territory, and in particular protected areas, are now called upon to pursue (Moses 2007). While there are many difficulties, these can and must be overcome in order to modernize protected areas and promote sustainable development.

\section{Acknowledgements}

We would like to thank Paolo Giupponi and Chiara Gastoldi for their help during our visits to the study area.

This study was supported by Accordo di collaborazione fra Regione Lombardia e Ge.S.Di.Mont. per attività di ricerca scientifica ed applicata e di diffusione della conoscenza inerente il territorio montano lombardo (art. 4 c.7 1.r. 22/2016).

\section{References}

Admiraal, J.F., C.J.M. Musters \& G.R de Snoo 2016. The loss of biodiversity conservation in EU research programmes: Thematic shifts in biodiversity wording in the environment themes of EU research programmes FP7 and Horizon 2020. Journal of Nature Conservation 30: 12-18. Available at: http://www.sciencedirect. com/science/article/pii/S161713811530039X

Aeschimann, D. \& H.M. Burdet 1989. Flore de la Suisse et des territoires limitrophes. Neuchâtel, Suisse. [In French]

Aeschimann D., K. Lauber, D.M. Moser \& J.-P. 2004. Flora alpina. Bern-Stuttgart-Wien. [In German]

ALPARC 2016. Rapport annuel 2015. Réseau alpin des espaces protégés, Chambéry. [In French]
Andreis, C. 2002. I distretti geobotanici. In: Del Favero, R. (ed.), I tipi forestali della Lombardia: 36-40. Verona. [In Italian]

Andreis, C. \& G. Rinaldi 1989. Contributo alla conoscenza delle praterie a Festuca scabriculmis ssp. luedii dei versanti meridionali delle Alpi Orobie. Riv. Mus. Civ. Sc. Nat. "E. Caffi", Bergamo 14: 81-98. Available at: http://www.museoscienzebergamo.it/web/images/ stories/museo/Rivista_museo/14_volume/riv_14_ andreis_rinaldi.pdf [In Italian]

Bell, S., L. Tyrväinen, T. Sievänen, U. Pröbstl \& M. Simpson 2007. Autdoor Recreation and Nature Tourism: A European Perspective. Living Reviews in Landscape Research 1(2): 1-46. Available at: http://lrlr.landscapeonline.de/Articles/lrlr-2007-2/

Bendotti, M. 1996. Precisazioni sulla Linaria tonzigii. Not. Florist. Flora Alpina Bergamasca 10: 24. [In Italian]

Blasi, C., G. Capotorti, R. Copiz, D. Guida, B. Mollo, D. Smiraglia \& L. Zavattero 2014. Classification and mapping of the ecoregions of Italy. Plant Biosystems 148(5-6): 1255-1345. Available at: http://www. tandfonline.com/doi/full/10.1080/11263504.2014.9 85756

Blasi, C., M. Marignani, R. Copiz, M. Fipaldini, S. Bonacquisti, E. Del Vico, L. Rosati \& L. Zavattero 2011. Important Plant Areas in Italy: from data to mapping. Biological Conservation 144: 220-226. Available at: http://www.sciencedirect.com/science/article/ pii/S0006320710003769

Brissoni, C. 2007. Sentiero dei Fiori Claudio Brissoni. Maggioni Lino S.r.l., Ranica (BG). [In Italian]

Casale, F., R. Dellavedova, P. Lenna, M. Perracino \& A. Rampa 2008. Atlante dei SIC della Lombardia. Isabel Litografia, Gessate (MI). [In Italian]

Ciapała, S., P. Adamsky, A. Mroczka, J. Svajda \& Z. Witkowski 2014. Threats related to tourism and recreation in Natura 2000 areas, based on the analysis of the standard data forms (SDF) from the Alpine Bioregion of Slovakia. eco.mont 6(2): 55-60. Available at: http://epub.oeaw.ac.at/eco.mont-6-2/?frames=yes

D'Adda, P. \& S. Zanchetta 2015. Geological-structural map of the Orobic and Porcile thrust junction, central Southern Alps (N Italy). Journal of Maps 11(1): 25-38. Available at: http://econpapers.repec.org/article/taftjomxx/ v_3a11_3ay_3a2015_3ai_3a1_3ap_3a25-38.htm

Dixon, P. 2003. Vegan, a package of $\mathrm{R}$ functions for community ecology. Journal of Vegetation Science 14: 927-930. Available at: http://onlinelibrary.wiley.com/ doi/10.1111/j.1654-1103.2003.tb02228.x/abstract

Eagles, P.F.J. 2009. Governance of recreation and tourism partnerships in parks and protected areas. Journal of Sustainable Tourism 17(2): 231-248. Available at: http://www.tandfonline.com/doi/ pdf/10.1080/09669580802495725

Fenaroli, L. 1954. Beitrage zur Kenntnis eines neuen Endemiten der Ostalpen: Linaria tonzigii Lona. Angewandte Pfanzensoziologie 1: 125-126. [In German] 
Giacomini, V. \& L. Fenaroli 1958. La flora. Milano. [In Italian]

Giorgi, A. \& T. Scheurer 2015. Alpine Resources: Assets for a Promising Future - Conclusions from the ForumAlpinum 2014. Mountain Research and Development 35(4): 414-415. Available at: http://www.bioone.org/ doi/pdf/10.1659/MRD-JOURNAL-D-15-00061

Hammer, T., I. Mose, T. Scheurer, D. Siegrist \& N. Weixlbaumer 2012. Societal research perspectives on protected areas in Europe. eco.mont 4(1): 5-11. Available at: http://epub.oeaw.ac.at/eco.mont-4$1 /$ ?frames $=$ yes

Hammer, T. \& D. Siegrist 2008. Protected Areas in the Alps - The Success Factors of Sustainable Tourism and the Challenge for Regional Policy. GAIA 17 (1): 152-160. Available at: http://www.ingentaconnect. com/contentone/oekom/gaia/2008/00000017/ A00101s1/art00013

Körner, C. 2003. Alpine plant life. Functional plant ecology of high mountain ecosystems. Berlin, Heidelberg.

Körner, C. 2014. Mountain ecosystems in a changing environment. eco.mont 6(1): 71-77. Available at: http:/ / epub.oeaw.ac.at/eco.mont-6-1/?frames=yes

Landolt, E., B. Bäumler, A. Erhardt, O. Hegg, F. Klötzli, R.W. Lämmle, M. Nobis, K. Rudmann-Mayree, H.F. Schweingruber, J.P. Theurillat, E. Urmi, M. Vust \& T. Wohlgemuth 2010. Flora indicativa. Ökologische Zeigerwerte und biologische Kennzeichen zur Flora der Schweiz. und der Alpen. Bern-Stuttgart-Wien. [In German]

McCool, S. \& J. Priskin 2006. Managing for visitor experiences in protected areas: promising opportunities and fundamental challenges. Parks 16 (2): 3-9. Available at: https://iucn.oscar.ncsu. edu/mediawiki/index.php/PDF:_Managing_for_ visitor_experiences_in_protected_areas:_Promising_ opportunities_and_fundamental_challenges

Lona, F. 1949. Nuova specie di Linaria rinvenuta al Pizzo Arera (Alpi Orobie). Natura, Riv. Sc. Nat., Ed. Soc. ital. Sc. Nat., Milano XL (3-4): 65-72. [In Italian]

Martini, F. (ed.), E. Bona, G. Federici, F. Fenaroli \& G. Perico 2012. Flora vascolare della Lombardia centroorientale. Vol 1. LINT, Trieste. [In Italian]

Melo, L., J. Abreu \& T. Silva 2014. Mobile applications for natural parks: guidelines study for the development of a mobile device application. Procedia Technology 16: 263-268. Available at: http://www.sciencedirect. com/science/article/pii/S2212017314003181

Metsähallitus 2000. The Principles of Protected Area Management in Finland: Guidelines on the Aims, Function and Management od State-owned Protected Areas. Nature Protection Publications of the Finnish Forest and Park Service. Series B, No. 54, Helsinki (Metsähallitus).

Mose, I. (ed.) 2007. Protected Areas and Regional Development in Europe. Towards a New Model for the $21^{\text {st }}$ Century. Hampshire, Burlington.

Newsome, D., S.A. Moore \& R.K. Dowling 2009. Natural Area Tourism. Ecology, Impacts and Management. Aspects of Tourism 4. Buffalo.
Palombo, C., M. Marchetti \& R. Tognetti. Mountain vegetation at risk: current perspectives and research reeds. Plant Biosystems 148: 35-41. Available at: http:/ / www.tandfonline.com/doi/abs/10.1080/11263504.2 013.878410

Pawlowski, B. 1970. Remarques sur l'endémisme dans la flore des Alpes et des Carpates. Vegetatio 21: 181-243. [In French]

Pignatti, S. 1982. Flora d'Italia. Bologna. [In Italian]

Pignatti, E. \& S. Pignatti 1975. Syntaxonomy of the Sesleria varia-grasslands of the calcareous Alps. Vegetatio 30(1): 5-14. Available at: https://www.jstor.org/ stable/20036834?seq=1\#page_scan_tab_contents

Pignatti, E., S. Pignatti 2014. Plant Life of the Dolomites. Vegetation Structure and Ecology. Heidelberg.

Pitschmann, H. \& H. Reisigl 1959. Endemische Blütenpflanzen der Südalpen zwischen Luganersee und Etsch. Veröffentlichungen des Geobotanischen Institutes, Stiftung Rübel in Zürich 35: 44-68. [In German]

Provincia di Bergamo, Dipartimento di Scienze della Terra dell'Università degli Studi di Milano, Dipartimento di Scienze Geologiche e Geotecnologie dell’Università degli Studi di Milano Bicocca \& Centro di Studio per la Geodinamica e Quaternaria del CNR 2000. Carta geologica della Provincia di Bergamo. Provincia di Bergamo, Bergamo. [In Italian]

R Core Team 2015. R: A language and environment or statistical computing. R Foundation for Statistical Computing, Vienna, Austria. Available at: http:// www.r-project.org

Raunkiaer, C. 1934. The life form of plants and statistical plant geography. Oxford.

Ravazzi, C. 1992. Lineamenti fisionomici, ecologia e fattori edafici della vegetazione di alcuni massicci calcareo-dolomitici delle Prealpi Lombarde. Natura Bresciana, Riv. Mus. Civ. Sc. Nat. Brescia 27: 11-49. Available at:http://www.comune.brescia. it/servizi/arteculturaeturismo/museoscienze / Pagine/1990_1991_27_11-51_Ravazzi.aspx [In Italian]

Reisigl, H. 1995. Insubrien und das Gardaseegebiet. Vegetation, Florengeschichte, Endemismus. Annali del Museo Civico di Rovereto 11: 9-25. [In German]

Reisigl, H. \& R. Keller 1990. Fiori e ambienti delle Alpi. Trento. [In Italian]

Sandifer, P.A., A.E. Sutton-Grier \& B.P. Ward 2015. Exploring connections among nature, biodiversity, ecosystem services, and human health and well-being: Opportunities to enhance health and biodiversity conservation. Ecosystem Services 12: 1-15. Available at: http://www.sciencedirect.com/science/article/pii/ S2212041614001648

Sutter, R. 1962. Das Caricion austroalpinae ein neuer insubrisch-sudalpiner Seslerietalia-Verband. Mitteilungen der Ostalpinen Dinarischen Pflanzensoziologischen Arbeitsgemeinschaft 2(1): 18-22. [In German]

Valoti, M. 1996. Distribuzione territoriale di Linaria tonzigii Lona (Scrophulariaceae) in Bergamasca. Not. Florist. Flora Alpina Bergamasca 9: 13-14. Available at: http://www.floralpinabergamasca.net/archivio/ 
downloads/notiziari/Notiziario \%20FAB\%2009.pdf [n Italian]

Verde, S., S. Assini \& C. Andreis 2010. Le serie di vegetazione della regione Lombardia. In: Blasi, C. (ed.), La vegetazione d'Italia: 181-203. Roma. [In Italian]

\section{Authors}

\section{Luca Giupponi}

is a botanist of Ge.S.Di.Mont., an expert in the flora of the Alps, plant ecology and phytosociology. He deals with the study of plants and plant communities and everything related to the valorization of mountain areas. Email: luca.giupponi@unimi.it

\section{Annamaria Giorgi ${ }^{1,2}$}

is the director of Ge.S.Di.Mont. and is experienced in the management of public institutions dealing with research activities. She was formerly the president of ISCAR and now represents the Lombardy Region in the EU Strategy for the Alpine Region. Email: anna.giorgi@unimi.it

${ }^{1}$ Centre of Applied Studies for the Sustainable Management and Protection of Mountain Areas, (Ge.S.Di.Mont.), University of Milan, Via Morino 8, Edolo, 25048 Brescia, Italy.

${ }^{2}$ Department of Agricultural and Environmental Sciences - Production, Landscape, Agroenergy (DISAA), University of Milan, Via Celoria 2, 20133 Milan, Italy. 